\title{
Türkiye'de Tüketici Fiyatları ile Hedonik Konut Fiyatları Arasındaki İlişki: Panel Veri Analizi
}

\section{The Relationship between Hedonic House Prices and Consumer Prices in Turkey: Panel Data Analysis}

\author{
Can SAĞLAM, Karadeniz Teknik Üniversitesi, Türkiye, cansaglam@outlook.com.tr \\ Orcid No: 0000-0003-0688-4698 \\ Zehra ABDİOĞLU, Karadeniz Teknik Üniversitesi, Türkiye, maras@ktu.edu.tr \\ Orcid No: 0000-0002-1653-2840
}

\begin{abstract}
Öz: Konut fiyatlarında meydana gelen dalgalanmalar ekonomik dinamikleri önemli ölçüde etkilemektedir. Bu bağlamda, konut fiyatlarını etkileyen mikro ve makroekonomik değișkenlerin belirlenmesi önemli bir konudur. Bu çalıșmanın amacl, Türkiye'de 26 bölge bazında 2010:01-2018:02 dönemi itibariyle hedonik konut fiyatlarl ile tüketici fiyatları arasındaki kısa ve uzun dönemli dinamik ilişkileri test etmektir.

Calıșadan edinilen ampirik bulgulara göre, hedonik konut fiyat endeksi ile tüketici fiyat endeksi arasında eşütünleșme iliskisi söz konusudur. Ayrıca tüketici fiyatları hem kisa hem de uzun dönemde hedonik konut fiyatların etkilemektedir. Uzun dönemde tüketici fiyat endeksinde meydana gelecek $\% 10$ ’luk bir artış hedonik konut fiyat endeksini yaklaşık olarak\%8.5 arttırmaktadır. Hata düzeltme terimi değişkenler arasındaki uzun dönem denge ilişkisini doğrulamaktadır.
\end{abstract}

Anahtar Sözcükler: Türkiye Ekonomisi, Hedonik Konut Fiyat Endeksi, Tüketici Fiyat Endeksi, Panel Veri Analizi JEL Sinıflandirmasi: C23, E31, R31

Abstract: Fluctuations in housing prices have a significant effect on economic dynamics. In this context, the determination of micro and macroeconomic variables affecting housing prices is an important issue. The aim of this study is to test the short-run and the long-run dynamic relationship between the hedonic house prices and the consumer prices in Turkey based on 26 regions for the period 2010:01-2018:02.

According to the empirical findings, there is a co-integration relationship between the hedonic house price index and the consumer price index. In addition, consumer prices affect the hedonic housing prices in both short-run and long-run. In the long-run, a 10\% increase in the consumer price index increases the hedonic price index by approximately $8.5 \%$. The error-correction term confirms the long-run equilibrium relationship between variables.

Keywords: Turkish Economy, Hedonic House Price Index, Consumer Price Index, Panel Data Analysis JEL Classification: C23, E31, R31

\section{Giriş}

Hane halkı açısından barınma amacına hizmet eden ve dayanıklı bir tüketim malı olan konut aynı zamanda sermaye malı olarak da önemli bir yatırım aracıdır. Özellikle gelişmiş ülkelerin hane halkı harcamalarının azımsanmayacak bir bölümünün konut harcamalarından meydana geldiği ve bu ülkelerde konut yatırımlarının milli gelir içindeki payının yüksek olduğu bilinmektedir. Bu nedenle konut fiyatlarında meydana gelen dalgalanmalar ekonomik dinamikler üzerinde önemli düzeyde etki yaratabilmekte ve konut piyasasında yaşanan gelişmeler başta bankacılık ve inşaat olmak üzere birçok sektörü etkilemektedir.

Konut fiyatları çok sayıda girdinin fiyatını barındırdığı için bu girdilerin fiyatlarında meydana gelen değişimler konut fiyatlarını etkilemektedir. Fiyatlar genel seviyesindeki artışlar karşısında artan girdi maliyetleri inşaat maliyetlerini artırarak konut stokunun azalmasına neden olmaktadır. Bunun yanı sıra enflasyonist bir ortamda toplam kredi stokunda önemli bir paya sahip olan konut kredilerini temin eden kuruluşların izledikleri sıkılaştırıcı politikalar kredi faizlerini yükseltmektedir. Kredi faizlerindeki artış ile ortaya çıkan borçlanma maliyeti kredi ile konut sahibi olmak isteyenlerin sayısını azaltmaktadır.

Enflasyonun gayrimenkul getirileri üzerindeki etkisi 1970'li yıllardan beri yatırımcılar açısından önem arz eden konuların başında gelmiştir. Her ne kadar 1990'lı yıllarda enflasyon yavaşlama eğilimi içine girmiş olsa da 2007-2009 döneminde yaşanan küresel finansal kriz ve küresel enflasyon, enflasyon ile gayrimenkul getirisi arasındaki ilişkinin yeniden ön plana çıkmasına neden olmuştur (Lee, 2013: 207). Küresel anlamda konut fiyatlarının özellikle 2000'lerin başından itibaren ciddi bir artı̧s eğiliminde olduğu dikkat çekmektedir. Bu artış eğiliminin 2008 yllında yaşanan küresel krize kadar devam ettiği görülmektedir. Bu süreçte yükselen konut fiyatlarına sebep olan artan konut talebi, inşaat sektörünün ekonomik büyümeye ivme kazandıran sektörlerin başında yer almasına neden olmuştur. Ancak 2008 yılında yaşanan küresel krizle birlikte tüm dünyada konut fiyatları oldukça sert düşüşler yaşamıştır.

Enflasyonun konut piyasası ve konut talebi üzerindeki etkileri farklı görüşler ile pek çok çalışma tarafindan ele alınmışıır. Literatüre bakıldığında, konut inşaatında meydana gelen keskin artışlara neden olan en önemli etkenlerden biri olarak enflasyon ile gelir vergisi etkileşimine dikkat çekildiği görülmektedir (Feldstein, 1980; Hendershott, 1980; Poterba,

Makale Gecmiși / Article History

Başvuru Tarihi / Date of Application Kabul Tarihi / Acceptance Date
: 13 Temmuz / July 2019

: 14 Ekim / October 2019 
1992). Feldstein (1992) artan enflasyonun bireylerin konuta yatırım yapma eğilimlerini azalttığını ve bu nedenle konut talebini olumsuz etkilediğini vurgulamıştır. Kearl (1979) ise konut alımlarının çoğunun sabit oranlı bir ödeme ipoteği ile finanse edildiğine dikkat çekerek, bu durumda enflasyon beklentilerinde meydana gelen artışın nominal konut ödemelerini arttıracağını, hane halkı tasarruf ve varlıklarını azaltacağını ve nihai olarak enflasyonun konut talebini olumsuz yönde etkileyeceğini vurgulamıştır. Buna karşın Andrews (2010) enflasyonda yaşanan değişimlerin konut fiyatlarında artış eğilimine neden olduğunu tespit etmiştir. Nielsen ve Sorensen (1994) enflasyonda meydana gelen artışın, vergi sonrası reel kullanıcı maliyetlerinde yaşanan azalışlardan dolayı bireylerde konut yatırımı güdüsü yarattığını savunmuştur. Enflasyonun konut talebine olan etkisi konut fiyatlarını şekillendirmektedir. Konut yatırımı yapan bireyler konutun piyasa değerini koruma ve artırma kapasitesine önem göstermektedir. Bu kapsamda literatürde gayrimenkul fiyatlarının enflasyona karşı koruma kabiliyeti üzerinde duran pek çok çalışma olduğu (Fama ve Schwert, 1977; Reilly vd., 1977; Spellman, 1981; Rubens vd., 1989; Bond ve Seiler, 1998; Chaudhry vd., 1999; Sing ve Low, 2000; Anari ve Kolari, 2002; Chu ve Sing, 2004; Goetzmann ve Volaitis, 2006; Zhou ve Clements, 2010; Lee, 2013) gözlenmektedir.

Türkiye için yapılan çalışmalar incelendiğinde özellikle konut fiyatlarını etkileyen faktörlerin belirlenmesine yönelik olarak gerçekleştirilen ve hedonik regresyon yaklaşımını baz alan mikro düzeydeki çalışmalara ağırlık verildiği gözlenmektedir (Üçdoğruk, 2001; Yankaya ve Çelik, 2005; Savuran, 2008; Mutluer, 2008; Selim, 2008; Baldemir vd., 2008; Selim ve Demirbilek, 2009; Cingöz, 2010; Kaya, 2012; Yayar ve Gül, 2014; Yayar ve Karaca, 2014; Kördiş vd., 2014; Bulut vd., 2015; Çiçek ve Hatırlı, 2015; Kangallı Uyar ve Yayla, 2016; Hülagü vd., 2016; Afşar vd., 2017). Türkiye ekonomisi için makro düzeyde konut fiyatları üzerinde makro ekonomik değişkenlerin etkisini inceleyen çalışmaların ise nispeten daha sinırlı olduğu (Badurlar, 2008; Karg1, 2013; Paksoy vd., 2014; Kayral, 2017; Erdem ve Yamak, 2018; Akkaya, 2018; Karaağaç ve Altınırmak, 2018; Kolcu ve Yamak, 2018; İslamoğlu ve Nazlığlu, 2019) görülmektedir. İlgili çalışmalardan sadece Kayral (2017), Erdem ve Yamak (2018) ve Akkaya (2018)'nın konut fiyatları kapsamında hedonik konut fiyatlarını baz aldıkları dikkatleri çekmektedir.

Konut fiyatları doğası gereği homojen bir yapıya sahip değildir. Konut fiyatlarındaki değişimlere konutun saf fiyat değişimleri sebep olabileceği gibi konutun kalite değişimleri de sebep olabilmektedir. Dolayısıyla bu değişimleri tam anlamıyla yorumlayabilmek için güvenilir bir konut fiyat endeksinin kullanılması önem arz etmektedir. Bu çalışmada Türkiye'de 26 alt bölge kapsamında 2010:01-2018:02 dönemi itibariyle geniş bir veri seti kullanılarak hedonik konut fiyatları ile tüketici fiyatları arasındaki kısa ve uzun dönemli dinamik ilişkilerin panel veri yaklaşımıyla araştırılması amaçlanmıştır. Çalışmanın birinci bölümünde ampirik literatüre yer verilmiştir. İkinci bölümde veri seti ve ekonometrik yöntem tanıtılmış ve üçüncü bölümde elde edilen ampirik bulgular sunulmuştur. Son olarak ise ampirik bulgular çerçevesinde sonuçlar tartışılmıştır.

\section{Ampirik Literatür Özeti}

Hedonik fiyat yöntemiyle ilgili ilk çalışmanın Haas (1922) tarafından tarım sektörüne yönelik gerçekleştirilen çalışma olduğu bilinmektedir. Daha sonra Waugh (1928) tarafından arazi özellikleri kapsamında yapılan çalışma ile uygulanmasına rağmen hedonik fiyat yöntemi teriminin literatürde ilk kullanımı Court (1939)'un otomobil fiyatlarındaki değişimi analiz etmeye yönelik yaptığı çalışması ile olmuştur (Colwell ve Dilmore, 1999: 620). Daha sonralarında bu yöntem Griliches $(1961,1971)$ ve Rosen (1974) tarafından yapılan çalışmalar ile birlikte kalite etkisi açısından uyarlanmış bir fiyat endeksi olarak yoğun bir şekilde incelenmiş ve yaygın hale gelmiştir. Bu doğrultuda ilk hedonik model Amerikalı iktisatçı Rosen (1974) tarafından Lancaster (1966)'ın tüketici teorisi kapsamında, mal karakteristiklerine dayalı olarak piyasa denge analizi ile ortaya koyulmuştur (Rosen, 1974: 37).

Hedonik fiyat modeli, konut heterojenliği nedeniyle kentsel konut piyasasını incelemek amacıyla yaygın olarak uygulanmaktadır. Türkiye için konut fiyatları özelinde literatüre bakıldığında gerek il bazında gerekse de bölge bazında hedonik fiyat modelleri ile konut fiyatlarını etkileyen faktörlerin çokça analiz edildiği görülmektedir. Bu çalışmalara örnek olarak; Üçdoğruk (2001) ve Yankaya ve Çelik (2005)'in İzmir ili için, Savuran (2008)'1n İstanbul ili Etiler bölgesi için, Yayar ve Gül (2014)'ün Mersin ili için, Yayar ve Karaca (2014)'nın TR83 (Tokat, Samsun, Çorum, Amasya) düzey bölgesi için, Kördiş vd. (2014)'nin Antalya ili için, Bulut vd. (2015)'nin Samsun ili için ve Afşar vd. (2017)'nin Eskişehir ili için yaptıkları çalışmalar gösterilebilir. Yapılan bu çalışmalar ele alınan iller veya bölgeler için mikro düzeyde konut fiyatlarının belirleyicileri ve hedonik konut fiyatları hakkında oldukça önemli bilgiler sağlamaktadır.

Makro düzeyde ise Anari ve Kolari (2002) Amerika Birleşik Devletleri (ABD) için konut fiyatları ile konut dışı mal ve hizmet fiyatları arasındaki uzun dönem ilişkiyi incelemişlerdir. 1968:01-2000:06 dönemine ilişkin veri setinin kullanıldığı çalışmada uzun dönem ilişkiyi ARDL modeli ile analiz ederek konut fiyatları ile konut dışı mal ve hizmet fiyatları arasında eşbütünleşme ilişkisinin varlığını tespit etmişlerdir. Anari ve Kolari (2002)'nin ortaya koydukları diğer bir sonuç ise konut dışı mal ve hizmet fiyatlarından elde edilen konut fiyatlarına ait Fisher katsayısının ele alınan dönem boyunca sabit ve 1'den büyük olduğudur. Elde edilen bulgular neticesinde, konut fiyatlarının uzun dönemde istikrarli bir şekilde enflasyondan korunma sağladığını ortaya koymuşlardır. Yine ABD için ticari ve yerleşik amaçlı konutların enflasyona karşı koruma sağlayıp sağlamadığını araştıran Goetzmann ve Volaitis (2006) 1978:02-2004:02 dönemi verileriyle VAR analizi kapsamında konutun uzun dönemde enflasyona karşı koruma niteliği taşıdığını tespit etmişlerdir.

Ma ve Liu (2008), 1989:01-1998:01 dönemi verilerini kullanarak Avustralya'nın 8 şehri (Adelaide, Canbera, Darwin, Sydney, Brisbane, Perth, Melbourne ve Hobart) için tüketici fiyatları ile konut fiyatları arasındaki ilişkiyi analiz etmişlerdir. Çalışmada ARDL sınır testi yöntemi kullanılarak konut fiyatları ile enflasyon arasında uzun dönemli bir ilişkinin var olduğu ayrıca tüketici fiyat endeksinin konut fiyatları üzerindeki etki düzeyinin şehirlere göre farklılık 
gösterdiği tespit edilmiştir. Inglesi-Lotz ve Gupta (2013), Güney Afrika için konut fiyatları ile konut dışı mal ve hizmet fiyatları arasında uzun dönemli ilişkiyi analiz ederek konut fiyatlarının enflasyona karşı herhangi bir koruma sağlayıp sağlamadığını incelemişlerdir. Çalışmalarında 1970:01-2011:01 dönemi için uzun dönemli ilişkiyi ARDL modeli ile analiz ederek hesaplanan Fisher katsayılarının teorik olarak beklenti yönünde olduğunu ve bu doğrultuda Güney Afrika'da konutun enflasyona karşı koruma niteliği taşıyan bir menkul değer olduğunu ortaya koymuşlardır. Bunun yanı sıra, Inglesi-Lotz ve Gupta (2013) enflasyonun konut fiyatları üzerindeki etkisinin konut segmentlerine göre farklılık teşkil edip etmediğini de analiz etmişlerdir. ARDL modeline ilişkin ampirik bulgular ele alınan altı segmentte konut fiyatları ile tüketici fiyat endeksi arasındaki uzun dönemli ilişkinin varlığını kanıtlamışlardır.

Türkiye ekonomisi için 1990-2006 dönemi itibariyle Badurlar (2008), konut fiyatları ile gayrisafi yurtiçi hasıla, para arzı, kısa dönem faiz oranları ve döviz kuru arasındaki uzun dönem ilişkiyi Johansen eşbütünleşme yaklaşımı ile test ederek konut fiyatları ile makroekonomik değişkenler arasında uzun dönem denge ilişkisinin varlığını ortaya koymuştur. Karg1 (2013), 2000:01-2012:03 dönemine ilişkin veri seti kapsamında konut fiyatları ile ekonomik büyüme ve enflasyon arasındaki nedensellik ilişkişkisini Granger nedensellik testi ile araştırarak değişkenler arasında çift yönlü nedensellik ilişkisi olduğu yönünde bulgulara ulaşmıştır. Paksoy vd. (2014), Türkiye geneli ve TRC1 (Gaziantep, Adıyaman, Kilis), TRC2 (Şanlıurfa, Diyarbakır) ve TRC3 (Mardin, Batman, Şırnak, Siirt) düzey bölgeleri için konut fiyat endeksinin enflasyonist baskıya sebep olup olmadığını incelemişlerdir. Bu amaçla, 2010:01-2014:01 dönemi verilerini kullanmışlardır. Konut fiyatları ve enflasyon arasındaki ilişkiyi Hacker-Hatemi-J bootstrap nedensellik testi ile sınayan Paksoy vd. (2014), konut fiyatlarının Türkiye genelinde herhangi bir enflasyonist baskıya neden olmadığını buna karşın konut fiyatlarının TRC1 ve TRC2 düzey bölgelerinde enflasyonist baskı yarattığını saptamışlardır.

Türkiye geneli ve 11 düzey bölgeye ait konut fiyat endeksleri ile tüketici fiyat endeksi arasındaki nedensellik ilişkisini inceleyen Karaağaç ve Altınırmak (2018) çalışmalarında 2010:01-2017:04 dönemi itibariyle Granger nedensellik testi kapsamında Türkiye geneli ve TR31 (İzmir), TR21 (Edirne, Kırklareli, Tekirdağ), TRC3 (Batman, Mardin, Siirt, Şırnak) düzey bölgelerine ait konut fiyat endeksinden tüketici fiyat endeksine doğru tek yönlü nedensellik ilişkisi tespit etmişlerdir. Ayrıca, tüketici fiyat endeksinden TRC1 (Kilis, Adıyaman, Gaziantep) düzey bölgesi konut fiyat endeksine doğru tek yönlü nedensellik ilişkisi olduğu yönünde bulgulara ulaşmışlardır. İstanbul, Ankara ve İzmir illeri için 2010:012017:04 dönemini kapsayan panel veri analizi ile enflasyonun konut fiyatları üzerindeki etkisini tespit etmeyi amaçlayan İslamoğlu ve Nazlığlu (2019), enflasyon oranı ile konut fiyatları arasında pozitif yönlü bir ilişki olduğunu, enflasyonda meydana gelecek olan \%1'lik bir artışın yaklaşık olarak \%0.9 oranında konut fiyatlarını arttıracağını vurgulamışlardır.

Kalite artışından arındırındırılmış hedonik konut fiyat endeksi üzerine odaklanan Kayral (2017), 2010:01- 2016:08 dönemi için İstanbul, Ankara ve İzmir illerine ait hedonik konut fiyat endeksi üzerinde bölgedeki diğer şehirlerin konut fiyat hareketlerinin, para ve sermaye piyasalarına ait değişkenlerin etkisini ileri doğru seçim analizi ile araştırmıştır. Ankara ve İzmir'in konut fiyatlarındaki değişimin büyük şehirlerin konut fiyatlarından etkilendiği, İstanbul'da konut fiyatlarındaki değişimin hem büyük şehirlerin konut fiyatlarından hem de borsa endeksi ve enflasyondan etkilendiği yönünde bulgulara ulaşmıştır. Erdem ve Yamak (2018), hedonik konut fiyat endeksi ile tüketici fiyat endeksi arasındaki kısa ve uzun dönemli dinamikleri belirlemeyi amaçlamışlardır. ARDL yöntemini kullanarak hem Türkiye genelinde hem de düzey bölgelerde (TR10; İstanbul, TR51; Ankara, TR31; İzmir, TR83; Samsun, Amasya, Çorum, Tokat, TR90; Artvin, Giresun, Gümüşhane, Ordu, Rize, Trabzon) tüketici fiyatlarının hedonik konut fiyatları üzerinde pozitif bir etkiye sahip olduğunu tespit etmişlerdir. Çalışmada tüketici fiyat endeksinin kısa ve uzun dönemde hedonik konut fiyat endeksi üzerinde istatistiksel olarak anlamlı etkilerinin olduğu sonucuna ulaşılmıştır. Son olarak Akkaya (2018), Türkiye'de 2010:01-2017:03 dönemi itibariyle hedonik konut fiyat endeksi ile tüketici fiyatları endeksi, sanayi üretim endeksi, işsizlik oranı gibi çeşitli makroekonomik değişkenler arasındaki ilişkiyi ARDL sınır testi yaklaşımı ve Granger nedensellik analizi ile test etmiştir. Ele alınan makro ekonomik değişkenlerin birçoğundan hedonik konut fiyat endeksine doğru tek yönlü nedensellik ilişkisi olduğu yönünde bulgulara ulaşmıştır.

\section{Veri Seti ve Ekonometrik Yöntem}

Bu çalışmanın amacı, hedonik konut fiyatları ile tüketici fiyatları arasında uzun dönemli ilişkiyi test etmektir. Bu amaçla çalışmada, Türkiye'nin 26 düzey bölgesine ilişkin 2010:01-2018:02 (üçer aylık) dönemini kapsayan panel veri seti kullanılmıştır. Çalışmanın ekonometrik analizinde kullanılan değişkenler Türkiye Cumhuriyet Merkez Bankası Elektronik Veri Dağıtım Sistemi'nden (TCMB - EVDS) edinilmiştir. Ele alınan değişkenlerin tamamı logaritmik dönüşüme tabi tutulmuşlardır. Değişkenlere ilişkin kısaltmalar ve tanımlamalar Tablo 1'de sunulmuştur.

Tablo 1. Değişkenlere İlişkin Kısaltma ve Tanımlamalar

\begin{tabular}{l|l}
\hline \hline Değişken Kısaltmaları & Değişken Tanımları \\
\hline LHKFE & Logaritmik Hedonik Konut Fiyat Endeksi $(2010=100)$ \\
\hline LTÜFE & Logaritmik Tüketici Fiyat Endeksi $(2003=100)$ \\
\hline \hline
\end{tabular}

Panel veri setinin yatay kesit boyutunu oluşturan Türkiye'ye ait 26 düzey bölgeleri ve düzey bölgelerin içerdiği iller Tablo 2'de gösterilmiştir. 
Tablo 2. Düzey Bölgeler ve Düzey Bölgeleri Oluşturan İller

\begin{tabular}{|c|c|}
\hline Bölge & Bölgeyi Oluşturan İller \\
\hline 1. Bölge (TR10) & İstanbul \\
\hline 2. Bölge (TR21) & Tekirdağ, Edirne, Kırklareli \\
\hline 3. Bölge (TR22) & Balıkesir, Çanakkale \\
\hline 4. Bölge (TR31) & İzmir \\
\hline 5. Bölge (TR32) & Aydın, Denizli, Muğla \\
\hline 6. Bölge (TR33) & Manisa, Afyon, Kütahya, Uşak \\
\hline 7. Bölge (TR41) & Bursa, Eskişehir, Bilecik \\
\hline 8. Bölge (TR42) & Kocaeli, Sakarya, Düzce, Bolu, Yalova \\
\hline 9. Bölge (TR51) & Ankara \\
\hline 10. Bölge (TR52) & Konya, Karaman \\
\hline 11. Bölge (TR61) & Antalya, Isparta, Burdur \\
\hline 12. Bölge (TR62) & Adana, Mersin \\
\hline 13. Bölge (TR63) & Hatay, Kahramanmaraş, Osmaniye \\
\hline 14. Bölge (TR71) & Kırıkkale, Aksaray, Niğde, Nevşehir, Kırşehir \\
\hline 15. Bölge (TR72) & Kayseri, Sivas, Yozgat \\
\hline 16. Bölge (TR81) & Zonguldak, Karabük, Bartın \\
\hline 17. Bölge (TR82) & Kastamonu, Çankırı, Sinop \\
\hline 18. Bölge (TR83) & Samsun, Tokat, Çorum, Amasya \\
\hline 19. Bölge (TR90) & Trabzon, Ordu, Giresun, Rize, Artvin, Gümüşhane \\
\hline 20. Bölge (TRA1) & Erzurum, Erzincan, Bayburt \\
\hline 21. Bölge (TRA2) & Ağrı, Kars, Iğdır, Ardahan \\
\hline 22. Bölge (TRB1) & Malatya, Elazı̆̆g, Bingöl, Tunceli \\
\hline 23. Bölge (TRB2) & Van, Muş, Bitlis, Hakkari \\
\hline 24. Bölge (TRC1) & Gaziantep, Adıyaman, Kilis \\
\hline 25. Bölge (TRC2) & Şanlıurfa, Diyarbakır \\
\hline 26. Bölge (TRC3) & Mardin, Batman, Şırnak, Siirt \\
\hline
\end{tabular}

Çalışmada ilk olarak değişkenlerin birim kök analizlerine yer verilmiştir. Birim kök sınamalarında öncelikle değişkenlerin birimleri arasında yatay kesit bağımlılı̆̆ın varlığı sınanmıştır. Serilerin birimleri arasında yatay kesit bağımlılık bulunup bulunmadığı Breusch ve Pagan (1980) Lagrange Çarpanı testi, Pesaran (2004) yatay kesit bağımlılık (CD) testi, Pesaran (2004) ölçeklendirilmiş Lagrange Çarpanı testi ve Baltagi vd. (2012) yanlılık düzeltmesi yapılmış Lagrange Çarpanı testi kullanılarak test edilmiştir. Yatay kesit bağımlılığın testinde panel birimleri arasında korelasyon bulunmadığını ileri süren sıfır hipotezi panel birimleri arasında yatay kesit bağımlılık olduğunu ifade eden alternatif hipoteze karşı test edilmektedir.

Panellerin birimleri arasında yatay kesit bağımlılık olması durumunda yatay kesit bağımlılığı dikkate alan ikinci nesil birim kök analizlerinin bulguları önem arz etmektedir. Pesaran (2007), serilerin birimleri arasında yatay kesit bağımlılığın varlığı durumunda yatay kesit genelleştirilmiş Dickey-Fuller (CADF) regresyonu üzerinden standart birim kök istatistiğine dayanan bir birim kök testi önermiştir. Standart ADF denklemine yatay kesit ortalamalara ilişkin gecikmeli değerler ve yatay kesit ortalamalarının birinci farkları ilave edilerek CADF denklemi elde edilmektedir. Pesaran (2007)'ın yaklaşımı bireysel yatay kesit ortalamalarla geniş̧letilmiş $\mathrm{ADF}$ istatistiklerinin $\left(\mathrm{CADF}_{\mathrm{i}}\right)$ basit aritmetik ortalamalarına dayanmaktadır. Bireysel CADF istatistikleri CIPS (yatay kesit genişletilmiş Im, Pesaran ve Shin) istatistiğinin elde edilmesinde kullanılmaktadır. CIPS istatistiği (1) numaralı eşitlikte gösterilmektedir.

$$
C I P S=N^{-1} \sum_{i=1}^{N} C A D F_{i}
$$


Birim kök analizleri sonrasında hedonik konut fiyat endeksi ile tüketici fiyat endeksi arasındaki uzun dönemli ilişki Kao (1999), Pedroni (1999, 2004) ve Westerlund (2007) panel eşbütünleşme testleriyle analiz edilmiştir. Kao (1999) ve Pedroni (1999, 2004), Engle-Granger eşbütünleşme testini genişleterek panel veriler kapsamında eşbütünleşme analizlerini gerçekleştirmişlerdir. Kao (1999), panel veri için Dickey-Fuller ve Genişletilmiş Dickey-Fuller olmak üzere hata terimi temelli iki çeşit eşbütünleşme testi önermiştir. (2) numaralı sabit etkiler modeli tahmin edilerek hata terimleri elde edilmektedir.

$$
y_{i t}=\alpha_{i}+\beta x_{i t}+e_{i t}
$$

Yardımcı regresyon denkleminin geniş̧letilmiş versiyonu aşağıdaki eşitlikte verilmiştir.

$$
e_{i t}=\rho e_{i t-1}+\sum_{j=1}^{p} \psi \Delta e_{i t-j}+v_{i t}
$$

Kao (1999), seriler arasında eş bütünleşme ilişkisinin olmadığını ifade eden sıfır hipotezine karşı eşbütünleşme ilişkisini savunan alternatif hipotezi test etmek üzere beş adet test istatistiği sunmuştur. (4) numaralı denklemde ADF test istatistiğine yer verilmiştir. (4) numaralı eşitlikte $t_{\mathrm{ADF}}$, (3) numaralı denklemdeki $\rho$ için $\mathrm{t}$ istatistiğidir. $\hat{\sigma}_{v}^{2}$, tahmini varyansı ve $\hat{\sigma}_{0 v}^{2}$, tahmini uzun dönem varyansı ifade etmektedir. ADF test istatistiğinin asimptotik dağılımı standart normal dağılıma N(0,1) yakınsamaktadır.

$$
A D F=\frac{t_{A D F}+\frac{\sqrt{6 N} \widehat{\sigma}_{v}}{2 \widehat{\sigma}_{0 v}}}{\sqrt{\frac{\widehat{\sigma}_{0 v}^{2}}{2 \widehat{\sigma}_{v}^{2}+\frac{3 \widehat{\sigma}_{v}^{2}}{10 \widehat{\sigma}_{0 v}^{2}}}}}
$$

Pedroni (1999), eş bütünleşme testi için dördü panel ve üçü grup test istatistiği olmak üzere parametrik ve parametrik olmayan toplam yedi adet test istatistiği önermiştir. Pedroni (1999), bu test istatistiklerinin her birinin asimptotik olarak standart normal dağılıma uyduğunu N $(0,1)$ göstermiştir. Eş bütünleşmenin olmadığını ifade eden $\rho_{i}=1$ şeklindeki sıfır hipotezine karşılık iki alternatif hipotez söz konusudur. Homojen alternatif hipotez $\left(\rho_{i}=\rho\right)<1$ (panel istatistiği) şeklinde ifade edilirken; heterojen alternatif hipotez $\rho_{i}<1$ (grup istatistiği) şeklinde ifade edilmektedir.

Westerlund (2007), hata düzeltme modeline dayalı bir panel eş bütünleşme yaklaşımı geliştirmiştir. Westerlund yaklaşımı, panel hata düzeltme modelinde hata düzeltme katsayısının sıfıra eşit olup olmadığına karar vererek değişkenler arasında eşbütünleşme ilişkisi olmadığını ileri süren sıfır hipotezini alternatif hipoteze karşı test etmektedir. Tüm test istatistikleri normal dağılıma sahip olmakla birlikte birimlere özgü kısa dönem dinamiklerini, birimlere özgü trend ve eğim parametrelerini ve yatay kesit bağımlılı̆̆ı barındırmaktadır. 4 adet panel eşbütünleşme testinden ikisi (Pt ve Pa) herhangi bir hata düzeltmenin söz konusu olmadığını ileri süren sıfır hipotezine karşı panelin bir bütün olarak eşbütünleşik olduğu yönündeki alternatif hipotezi test ederken; diğer ikisi (Gt ve Ga) paneli oluşturan birimlerden en az biri için hata düzeltmenin söz konusu olduğunu ifade eden heterojen alternatif hipotezi test etmektedir (Persyn and Westerlund, 2008: 233). Hata düzeltme modeli aşağıdaki (5) numaralı eşitlikte gösterilmiştir.

$$
\Delta y_{i t}=\delta_{i}^{\prime} d_{t}+\alpha_{i}\left(y_{i t-1}-\beta_{i}^{\prime} x_{i t-1}\right)+\sum_{j=1}^{p i} \alpha_{i j} \Delta y_{i t-j}+\sum_{j=0}^{p i} \gamma_{i j} \Delta x_{i t-j}+e_{i t}
$$

(5) numaralı denklemde $d_{t}=(1, t)$ deterministik bileşenler vektörünü ve $\alpha_{i}$ ani bir şok karşısında sistemin dengeye dönme hızını göstermektedir. Eğer $\alpha_{\mathrm{i}}<0$ ise $\mathrm{x}_{\mathrm{it}}$ ve $\mathrm{y}_{\mathrm{it}}$ serileri arasında eşbütünleşme ilişkisini orataya koyan hata düzeltmenin söz konusu olduğuna karar verilirken $\alpha_{\mathrm{i}}=0$ ise seriler arasında herhangi bir eşbütünleşme ilişkisi olmadığına karar verilmektedir. Westerlund (2007), kesit birimlerini etkileyen ortak faktörlerin varlığı nedeniyle diğer ifadeyle yatay kesit bağımlılık nedeniyle eşbütünleşme analizlerinde test istatistikleri için dirençli kritik değerlerin kullanılmasının önemine vurgu yaparak Chang (2004)'in bootstrap yaklaşımına benzer bir yaklaşım sunmuştur. Buna göre öncelikle x ve y serileri için bootstrap örneklemler elde edildikten sonra bootstrap hata düzeltme katsayısı elde edilmektedir. Başlangıç bootstrap istatistiği $t_{1}^{*}$ olarak tanımlanır ve ilgili süreç $S$ kez tekrarlanırsa $j=1,2, \ldots S$ için istatistiğin bootstrap dağılımı elde edilmiş olur $\left(t_{j}^{*}\right)$ (Westerlund, 2007: 723). Test istatistiği bootstrap kritik değeriyle kıyaslanarak seriler arasında eşbütünleşme ilişkisi olup olmadığına karar verilir.

Panel eşbütünleşme yaklaşımları ile seriler arasında eşbütünleşme ilişkisi tespit edilirse çeşitli yaklaşımlar çerçevesinde uzun ve kısa dönem katsayılar elde edilebilmektedir. Çalışmada Kao ve Chiang (2001) tarafından geliştirilen dinamik en küçük kareler (DOLS) ve Pedroni $(1996,2000)$ tarafindan geliştirilen tam değiştirilmiş en küçük kareler (FMOLS) yöntemleri kullanılarak uzun dönem katsayılar tahmin edilmiştir. FMOLS ve DOLS tahmincileri uzun dönemli ilişkide ortaya çıkan otokorelasyon ve içsellik sorunu için standart havuzlanmış OLS'yi düzeltmektedir. DOLS ayrıca uzun dönem denklemine dinamik unsurların girmesine olanak tanımaktadır. Kao ve Chiang (2001) gerçekleştirdikleri Monte Carlo çalışmaları neticesinde DOLS tahmincisinin sonlu örneklem özelliklerinin hem OLS hem de FMOLS tahmincisine göre daha iyi olduğunu tespit etmişlerdir.

Hem uzun hem de kısa dönemli dinamik ilişkinin tahmini ise Pesaran, Shin ve Smith (1999) tarafından geliştirilen havuzlanmış ortalama grup (PMG) ve Pesaran ve Smith (1995) tarafından geliştirilen ortalama grup (MG) tahmicileri ile gerçekleştirilmiştir. MG yaklaşımı her bir yatay kesit için tahmin edilen otoregresif gecikmesi dağıtılmış modelden (ARDL) elde edilen uzun dönem katsayılarının ortalamasını kullanarak uzun dönem katsayısını hesaplamaktadır. 
Dolayısıyla bu yöntemde her bir birim için uzun dönem katsayıları hesaplanabilmektedir. Diğer bir ifadeyle MG yönteminde uzun dönem katsayıların heterojen olduğu kabul edilmektedir. PMG yaklaşımı ise uzun dönem katsayılarının birimlere göre değişmediği yani homojen olduğu varsayımı üzerine kurulmuştur. Uzun dönem parametresinin birimlere göre değişip değişmediği Hausman (1978) testi ile sınanmaktadır. Hausman testinde uzun dönem parametrelerinin homojen olduğunu ifade eden sıfır hipotezi ilgili parametrelerin hetorejen olduğunu savunan alternatif hipoteze karşı test edilmektedir. Test sonucunda uzun dönem katsayılar açısından PMG ve MG tahmincileri arasında karar verilmektedir. Kısa dönem dinamikleri açısından bakıldığında ise her iki modelin de her bir yatay kesit için hata düzeltme modeli tahminine imkan tanıdı̆̆ı gözlenmektedir.

\section{Bulgular}

Çalışmada öncelikle 26 bölge bazında 2010:01-2018:02 dönemini kapsayan panel verilerin birim kök analizleri gerçekleştirilmiştir. Birim kök analizleri açısından değişkenlerin birimler arası yatay kesit bağımlılığa sahip olup olmadıklarının tespit edilmesi oldukça önem arz etmektedir. Eğer değişkenler yatay kesit bağımlılığa sahiplerse birinci kuşak birim kök testlerinden elde edilen bulgular güvenilir olmayacaktır. Dolayısıyla değişkenlerin yatay kesit bağımlılığa sahip olup olmadıkları çok sayıda yatay kesit bağımlılık testi ile analiz edilerek Tablo 3 'te sunulmuştur. Tablo 3 'teki bulgular incelendiğinde hem hedonik konut fiyat endeksi ve hem de tüketici fiyat endeksi için birimler arası yatay kesit bağımlılık olduğu gözlenmektedir.

Tablo 3. Yatay Kesit Bağımlılık Test Sonuçları

\begin{tabular}{c|c|c|c}
\hline \hline Değişken & Test Türü & Ístatistik & Olasılık \\
\hline \multirow{4}{*}{ LHKFE } & Breusch-Pagan LM & 10305.76 & 0.0000 \\
& Pesaran scaled LM & 390.4577 & 0.0000 \\
& Bias-corrected scaled LM & 390.0637 & 0.0000 \\
& Pesaran CD & 101.4554 & 0.0000 \\
\hline \multirow{3}{*}{ LTÜFE } & Breusch-Pagan LM & 11035.59 & 0.0000 \\
& Pesaran scaled LM & 419.0841 & 0.0000 \\
& Bias-corrected scaled LM & 418.6901 & 0.0000 \\
& Pesaran CD & 105.0504 & 0.0000 \\
\hline \hline
\end{tabular}

Serilerin kesitleri arasındaki bağımlılık dolayısıyla birim kök analizinde ilgili bağımlılığı dikkate alan CADF ikinci nesil panel birim kök testi kullanılmıştır. CADF panel birim kök testine ait bulgulara Tablo 4'de yer verilmiştir. 4 gecikmeye kadar tekrarlanan analizler sonucunda elde edilen test istatistikleri değerlendirildiğinde hedonik konut fiyat endeksi ve tüketici fiyat endeksi serilerinin seviyelerinde birim köke sahip oldukları, birinci farklarında ise birim kök içermedikleri belirlenmiştir. Diğer bir ifadeyle CADF panel birim kök testine göre seriler birinci farklarında durağandır.

Tablo 4. CADF Panel Birim Kök Test Sonuçları

\begin{tabular}{|c|c|c|c|}
\hline & $p$ & Sabitli & Sabitli-Trendli \\
\hline \multirow{5}{*}{ LHKFE } & 0 & -1.735 & -2.340 \\
\hline & 1 & -1.285 & -1.923 \\
\hline & 2 & -1.478 & -1.874 \\
\hline & 3 & -1.709 & -1.886 \\
\hline & 4 & -1.667 & -1.719 \\
\hline \multirow{5}{*}{$\triangle L H K F E$} & 0 & $-5.398 * * *$ & $-5.854 * * *$ \\
\hline & 1 & $-3.618 * * *$ & $-4.191 * * *$ \\
\hline & 2 & $-2.409 * * *$ & $-2.706 * *$ \\
\hline & 3 & $-2.034 *$ & -2.073 \\
\hline & 4 & -1.903 & -1.800 \\
\hline \multirow{5}{*}{$L T \ddot{U} F E$} & 0 & $-2.972 * * *$ & $-3.077 * * *$ \\
\hline & 1 & $-2.533 * * *$ & $-2.800 * * *$ \\
\hline & 2 & -1.988 & -2.391 \\
\hline & 3 & -1.698 & -1.955 \\
\hline & 4 & -1.665 & -1.838 \\
\hline \multirow{5}{*}{$\triangle L T \ddot{U} F E$} & 0 & $-6.040 * * *$ & $-6.223 * * *$ \\
\hline & 1 & $-4.373 * * *$ & $-4.398 * * *$ \\
\hline & 2 & $-3.851 * * *$ & $-4.017 * * *$ \\
\hline & 3 & $-2.484 * * *$ & -2.536 \\
\hline & 4 & $-2.125 * *$ & -2.236 \\
\hline
\end{tabular}

Not: ***, **ve * üst simgeleri strasılla \%1, \%5 ve \%10 anlamlllı düzeylerinde serinin durağan olduğunu ifade etmektedir. $\Delta$; fark operatörünü, p; CADF panel birim kök testi için gecikme uzunluğunu temsil etmektedir. 
Birinci devresel farklarında durağan olan hedonik fiyat endeksi ve tüketici fiyat endeksi arasındaki uzun dönem ilişki panel eşbütünleşme testleri vasıtasıyla sınanmıştır. Uygulanan eşbütünleşme testlerine ilişkin bulgular ise Tablo 5'te sunulmuştur. Pedroni panel eşbütünleşme testlerine ilişkin bulgular incelendiğinde ağırlıklandırılmamış panel istatistiklerinden v-istatistiği ve adf-istatistiğinin istatistiksel olarak \%1 düzeyinde anlamlı oldukları, ağırlıklandırılmış panel istatistiklerinin ise tamamının istatistiksel olarak en az $\% 5$ düzeyinde anlamlı oldukları gözlenmektedir. Bununla birlikte grup istatistiklerinden adf-istatistiğinin \%1 düzeyinde istatistiksel olarak anlamlı olduğu tespit edilmiştir.

Kao panel eşbütünleşme testine göre elde edilen test istatistiği tüketici fiyat endeksi ile hedonik konut fiyat endeksi arasında uzun dönem ilişkisi olduğunu ortaya koymuştur. Westerlund panel eşbütünleşme testinde ise grup istatistiklerinin $\% 1$ düzeyinde, panel istatistiklerinin ise en az \%5 düzeyinde istatistiksel olarak anlamlı oldukları tespit edilmiştir. Bununla birlikte tahmin edilen sabit etkiler modelininin hata terimine uygulanan CD testi sonucunda yatay kesit bağımlılık sorunu tespit edilmiştir. Yatay kesit bağımlılığın varlığında önerilen Westerlund panel eşbütünleşme testine ait bootstrap kritik değerleri ve buna bağlı olarak dirençli olasılık değerleri elde edilmiştir. Dirençli olasılık değerleri incelendiğinde test istatistiklerinin tamamının en az \%10 düzeyinde anlamlı oldukları görülmüştür. Uygulanan eşbütünleşme testlerinden elde edilen bulgulara göre hedonik konut fiyat endeksi ile tüketici fiyat endeksi arasında uzun dönem denge ilişkisi söz konusudur.

Tablo 5. Eşbütünleşme Test Sonuçları

\begin{tabular}{|c|c|c|c|c|}
\hline \multicolumn{5}{|c|}{ Pedroni Panel Eşbütünleşme Testleri Bulguları } \\
\hline & \multicolumn{4}{|c|}{ Bă̆ımlı De ğişken: LHKFE } \\
\hline Testler & \multicolumn{2}{|c|}{ Ağırlıklandırılmamış İstatistikler } & \multicolumn{2}{|c|}{ Ağırlıklandırılmış İstatistikler } \\
\hline Pedroni Panel v-İstatistiği & $2.5096^{* * *}$ & $(0.0060)$ & \multicolumn{2}{|c|}{$3.5304 * * * \quad(0.0002)$} \\
\hline Pedroni Panel rho-İstatistiği & -0.0070 & $(0.4972)$ & \multicolumn{2}{|c|}{$-1.8756 * * \quad(0.0304)$} \\
\hline Pedroni Panel pp-İstatistiği & -0.1077 & $(0.4571)$ & \multicolumn{2}{|c|}{$-2.0391 * * \quad(0.0207)$} \\
\hline Pedroni Panel adf-İstatistiği & $-4.5263 * * *$ & $(0.0000)$ & \multicolumn{2}{|c|}{$-4.6827 * * * \quad(0.0000)$} \\
\hline Pedroni Grup rho-İstatistiği & -0.5913 & $(0.2772)$ & \multicolumn{2}{|c|}{-} \\
\hline Pedroni Grup pp-İstatistiği & -1.2652 & $(0.1029)$ & \multicolumn{2}{|r|}{-} \\
\hline Pedroni Grup adf-İstatistiği & $-5.6652 * * *$ & $(0.0000)$ & & - \\
\hline \multicolumn{5}{|c|}{ Kao Panel Eşbütünleşme Test Bulgularl } \\
\hline & \multicolumn{4}{|c|}{ Băğmlı Değişken: LHKFE } \\
\hline Kao ADF-İstatistiği & \multicolumn{4}{|c|}{$\begin{array}{rr}-5.6284 * * * & (0.0000) \\
\end{array}$} \\
\hline \multicolumn{5}{|c|}{ Westerlund Panel Eşbütünleşme Testleri Bulguları } \\
\hline & \multicolumn{4}{|c|}{ Băğmlı Değişken: LHKFE } \\
\hline Testler & İstatistik & Z-istatistiği & Olasılik & Dirençli Olasılık \\
\hline $\mathrm{G}_{\mathrm{t}}$ & -2.583 & -4.528 & 0.000 & 0.030 \\
\hline $\mathrm{G}_{\mathrm{a}}$ & -13.014 & -5.469 & 0.000 & 0.010 \\
\hline $\mathrm{P}_{\mathrm{t}}$ & -9.282 & -1.741 & 0.041 & 0.080 \\
\hline $\mathrm{P}_{\mathrm{a}}$ & \begin{tabular}{l|l}
-7.988 & \\
\end{tabular} & -4.036 & 0.000 & 0.010 \\
\hline \multicolumn{5}{|c|}{ Sabit Etkiler Modeli Yatay Kesit Băğmlılık Testi } \\
\hline CD Test İstatistiği & \multicolumn{2}{|c|}{6.577} & Olasılık & 0.000 \\
\hline
\end{tabular}

Not: ***, **ve * üst simgeleri sırasıyla \%1, \%5 ve \%10 anlamlılık düzeylerinde eşbütünleşme ilişkisinin varlığını ifade etmektedir. Parantez içindeki değerler olasılık değerleridir. Eşbütünleşme testlerinde optimal gecikme uzunlukları Akaike bilgi kriterine (AIC) göre belirlenmiştir. Westerlund panel eşbütünleşme testinde bootstrap sayısı 100'dür.

Hedonik konut fiyatları ile tüketici fiyatları arasında eşbütünleşme ilişkinin tespit edilmesinin ardından kısa ve uzun dönemli katsayılar elde edilerek Tablo 6'da sunulmuştur. Tablo 6'dan DOLS ve FMOLS tahmincileriyle belirlenen uzun dönem katsayılarının birbirlerine oldukça yakın değerlere sahip oldukları görülmektedir. Ayrıca katsayılar incelendiğinde pozitif ve istatistiksel olarak \%1 düzeyinde anlamlı oldukları dikkatleri çekmektedir. Bu doğrultuda tüketici fiyat endeksindeki \%10'luk bir artışın, hedonik konut fiyat endeksini yaklaşık olarak \%11 oranında artıracağ ifade edilebilir.

$\mathrm{Bu}$ sonuçlara ek olarak değişkenler arasındaki kısa ve uzun dönemli dinamik ilişki PMG ve MG tahmincilerinden yararlanılarak belirlenmeye çalışılmıştır. Ele alınan modele ilişkin uzun dönem parametresinin homojen veya heterojen olup olmadığına Hausman testiyle karar verilmiştir.

Hausman testi ile uzun dönem parametresinin heterojen olduğunu ifade eden alternatif hipotez reddedilerek uzun dönem parametresinin homojen olduğuna karar verilmiştir. Bu doğrultuda PMG tahmincisinden edinilen bulgular değerlendirilmiştir. PMG yaklaşımıyla tahmin edilen uzun dönem katsayısı yaklaşık olarak 0.85 'tir ve \%1 düzeyinde istatistiksel olarak anlamlıdır. Dolayısıyla tüketici fiyat endeksinde meydana gelecek \%10'luk bir artış, hedonik konut fiyat endeksinde yaklaşık olarak \%8.5'luk bir artışa sebep olacaktır. Kısa dönem itibariyle PMG tahmincisinden elde edilen hata düzeltme katsayısı yaklaşık olarak -0.08'dir. Katsayı beklentiler doğrultusunda negatif ve istatistiksel olarak \%5 düzeyinde anlamlıdır. Tablo 7'de ise PMG ve MG tahmincilerinden elde edilen birimler için bireysel kısa ve uzun dönemli bulgular sunulmuştur. Bölgelerin çoğu için hata düzeltme terimi katsayısının beklentileri karşıladığı ve seriler arasındaki uzun dönem denge ilişkisini doğruladığı dikkatleri çekmektedir. 
Uzun dönem katsayısının tahmini konut fiyatlarının enflasyona karşı koruma mekanizması açısından önem ihtiva etmektedir. Şöyle ki, uzun dönem denklemde tüketici fiyatlarına ait kaysayının pozitif olması durumunda konut fiyatlarının enflasyona karşı koruma sağlayabildiği ifade edilmektedir. İlgili katsayının 1 ve 1 'den büyük olması durumunda ise konut fiyatlarındaki artışın tüketici fiyatlarındaki artışı tamamen telafi edebileceği ve dolayısıyla konut fiyatlarının enflasyona karşı mükemmel bir koruma sağlayabileceği varsayılmaktadır. Uzun dönem katsayının 0 ile 1 arasında olması durumunda ise konut fiyatları ile tüketici fiyatları arasında pozitif istikrarlı bir ilişkinin varlığından diğer bir ifadeyle konut fiyatlarının enflasyona karşı etkili bir koruma aracı olabileceğinden bahsedilmektedir (Arnold ve Auer, 2015: 189). Çalışmada DOLS ve FMOLS yaklaşımları kullanılarak elde edilen uzun dönem katsayılar bu kapsamda değerlendirildiğinde uzun dönemde hedonik konut fiyatlarının enflasyona karşı mükemmel koruma sağladığı söylenebilir. Bununla birlikte, PMG tahmincisinden elde edilen tüketici fiyatlarına ait uzun dönem katsayısı hedonik konut fiyatlarının enflasyona karşı oldukça etkili bir koruma sağladığına işaret olarak değerlendirilebilir.

Tablo 6. Panel Kısa ve Uzun Dönem Tahmin Sonuçları

\begin{tabular}{|c|c|c|c|c|}
\hline \multicolumn{5}{|c|}{ Uzun Dönem Katsayılar (Bağımlı Değișken: LHKFE) } \\
\hline & $P M G$ & $M G$ & DOLS & FMOLS \\
\hline$L T \ddot{U F E}$ & $0.8639 * * *$ & $1.2923 * * *$ & $1.1643 * * *$ & $1.1519 * * *$ \\
\hline \multicolumn{5}{|c|}{ Kısa Dönem Katsayılar (Bă̆ımlı Değişken: LHKFE) } \\
\hline Sabit Terim & $0.0323 * * *$ & $-0.232 * * *$ & - & - \\
\hline$\triangle L T \ddot{U} F E$ & $0.1019 *$ & $-0.0934 *$ & - & - \\
\hline$E C T$ & $-0.0803 * *$ & $-0.235 * * *$ & - & - \\
\hline \multicolumn{5}{|c|}{ Hausman Testi } \\
\hline Ki-Kare & \multicolumn{2}{|c|}{1.96} & & 0.1613 \\
\hline
\end{tabular}

Not: ***, **ve * üst simgeleri strasıla \%1, \%5 ve \%10 anlamlılık düzeylerinde ilgili katsayının anlamlı olduğ $u n u$ ifade etmektedir. ECT: Hata düzeltme terimidir. PMG ve MG tahmincilerine ilişkin tahminler için uygun ARDL modelinin ARDL $(1,1)$ olduğu belirlenmiştir.

Tablo 7. Bireysel Kısa ve Uzun Dönem Tahmin Sonuçları

\begin{tabular}{|c|c|c|c|c|c|c|c|c|c|}
\hline \multicolumn{3}{|c|}{ Bağımlı Değişken: LHKFE } & 1.Bölge & 2.Bölge & 3.Bölge & 4.Bölge & 5.Bölge & 6.Bölge & 7.Bölge \\
\hline \multirow{2}{*}{$\begin{array}{c}\text { Uzun } \\
\text { Dönem }\end{array}$} & \multirow{2}{*}{ LTÜFE } & $P M G$ & $0.8639 * * *$ & $0.8639 * * *$ & $0.8639 * * *$ & $0.8639 * * *$ & $0.8639 * * *$ & $0.8639 * * *$ & $0.8639 * * *$ \\
\hline & & MG & 5.7319 & 3.0372 & $1.8855^{* * *}$ & $1.6516^{* * *}$ & $1.7115^{* * * *}$ & $1.2460 * * *$ & $1.9829 * * *$ \\
\hline \multirow{6}{*}{$\begin{array}{c}\text { Kisa } \\
\text { Dönem }\end{array}$} & \multirow{2}{*}{$\begin{array}{l}\text { Sabit } \\
\text { Terim }\end{array}$} & $P M G$ & $0.0329 * * *$ & $0.0125^{* * *}$ & $0.0182 * * *$ & $0.0155 * * *$ & $0.018 * * *$ & $0.0243 * * *$ & $0.0088 * * *$ \\
\hline & & MG & 0.0757 & $-0.391 * * *$ & $-0.564 * * *$ & $-0.632 * * *$ & $-0.879 * * *$ & $-0.5375 * *$ & $-0.343 * * *$ \\
\hline & \multirow{2}{*}{$\Delta \mathrm{LTÜFE}$} & $P M G$ & 0.0044 & 0.0185 & -0.1063 & 0.0228 & 0.2589 & $0.1783 * *$ & -0.0012 \\
\hline & & MG & 0.0257 & -0.1786 & $-0.4302 *$ & -0.1869 & -0.2822 & -0.2307 & -0.1680 \\
\hline & \multirow{2}{*}{ ECT } & $P M G$ & $-0.006 * * *$ & $0.799 * * *$ & $0.0824 * * *$ & $0.0550 * * *$ & $0.0254 * * *$ & $-0.016 * * *$ & $0.0925 * * *$ \\
\hline & & MG & 0.0017 & -0.0357 & $-0.1088^{*}$ & $-0.1632 * *$ & $-0.2059 * *$ & $-0.3071 * *$ & -0.062 \\
\hline & & & 8.Bölge & 9.Bölge & 10.Bölge & 11.Bölge & 12.Bölge & 13.Bölge & 14.Bölge \\
\hline \multirow{2}{*}{$\begin{array}{c}\text { Uzun } \\
\text { Dönem }\end{array}$} & \multirow{2}{*}{ LTÜFE } & $P M G$ & $0.8639 * * *$ & $0.8639 * * *$ & $0.8639 * * *$ & $0.8639 * * *$ & $0.8639 * * *$ & $0.8639 * * *$ & $0.8639 * * *$ \\
\hline & & MG & $1.6415^{* * * *}$ & $1.1465 * * *$ & $1.3659 * * *$ & $1.5959 * * *$ & $1.9256^{*}$ & $1.1053 * * *$ & $0.9807 * * *$ \\
\hline \multirow{6}{*}{$\begin{array}{c}\text { Kısa } \\
\text { Dönem }\end{array}$} & \multirow{2}{*}{$\begin{array}{l}\text { Sabit } \\
\text { Terim }\end{array}$} & $P M G$ & $0.0184 * * *$ & $0.0233 * * *$ & 0.0233 & $0.0195 * * *$ & $0.0222 * * *$ & $0.0339 * * *$ & $0.0515 * * *$ \\
\hline & & MG & $-0.366 * * *$ & $-0.2659 * *$ & $-0.5963^{* *}$ & -0.2381 & -0.1571 & $-0.2639 * *$ & $-0.282 * * *$ \\
\hline & \multirow{2}{*}{$\Delta \mathrm{LTÜFE}$} & $P M G$ & 0.0070 & 0.0092 & $0.1271^{*}$ & $0.1574 * * *$ & $-0.11 * * *$ & 0.0054 & -0.0574 \\
\hline & & MG & -0.2638 & -0.2156 & -0.3153 & 0.0098 & -0.1979 & -0.2959 & $-0.4621 * *$ \\
\hline & \multirow{2}{*}{ ECT } & $P M G$ & $0.0304 * * *$ & $-0.011 * * *$ & $-0.0022 *$ & $0.0124 * * *$ & $0.0287 * * *$ & $-0.082 * * *$ & $-0.204 * * *$ \\
\hline & & MG & $-0.0948 *$ & $-0.2094 * *$ & $-0.2448^{* *}$ & -0.0334 & -0.0334 & $-0.2521 * *$ & $-0.630 * * *$ \\
\hline & & & 15.Bölge & 16.Bölge & 17.Bölge & 18.Bölge & 19.Bölge & 20.Bölge & 21.Bölge \\
\hline \multirow{2}{*}{$\begin{array}{c}\text { Uzun } \\
\text { Dönem }\end{array}$} & \multirow{2}{*}{ LTÜFE } & $P M G$ & $0.8639 * * *$ & $0.8639 * * *$ & $0.8639 * * *$ & $0.8639 * * *$ & $0.8639 * * *$ & $0.8639 * * *$ & $0.8639 * * *$ \\
\hline & & MG & 1.1780 **** & 0.8753 *** & $1.2386^{* * *}$ & $1.1702 * * *$ & $1.2744 * * *$ & $1.0300 * * *$ & $0.6086 * * *$ \\
\hline \multirow{6}{*}{$\begin{array}{c}\text { Kisa } \\
\text { Dönem }\end{array}$} & \multirow{2}{*}{$\begin{array}{l}\text { Sabit } \\
\text { Terim }\end{array}$} & $P M G$ & $0.0262 * * *$ & $0.1513 * * *$ & $0.0177 * * *$ & $0.0105 * * *$ & $0.0122 * * *$ & $0.0479 * * *$ & $0.0470 * * *$ \\
\hline & & MG & $-0.4261 * *$ & 0.1006 & $-1.067 * * *$ & $-0.244 * * *$ & $-0.343 * * *$ & -0.2031 & $0.5326^{* * *}$ \\
\hline & \multirow{2}{*}{$\Delta \mathrm{LTÜFE}$} & $P M G$ & $0.2253 * *$ & $-0.335 * *$ & $0.5937 * * *$ & $0.4073 * * *$ & $0.4094 * * *$ & $0.7997 * * *$ & $-0.6332 *$ \\
\hline & & MG & -0.1217 & -0.4029 & -0.1046 & 0.1372 & 0.0567 & 0.5344 & -0.4759 \\
\hline & \multirow{2}{*}{$\mathrm{ECT}$} & $P M G$ & $-0.041 * * *$ & $-0.842 * * *$ & $-0.018 * * *$ & 0.0109 & 0.0007 & $-0.184 * * *$ & $-0.197 * * *$ \\
\hline & & MG & $-0.2938 * *$ & $-0.845^{* * *}$ & $-0.611 * * *$ & $-0.1672 * *$ & $-0.1700 * *$ & $-0.3132 * *$ & $-0.337 * * *$ \\
\hline
\end{tabular}




\begin{tabular}{|c|c|c|c|c|c|c|c|c|c|}
\hline & & & 22.Bölge & 23.Bölge & 24.Bölge & 25.Bölge & 26.Bölge & - & - \\
\hline \multirow{2}{*}{$\begin{array}{c}\text { Uzun } \\
\text { Dönem }\end{array}$} & \multirow{2}{*}{ LTÜFE } & $P M G$ & $0.8639 * * *$ & $0.8639 * * *$ & $0.8639 * * *$ & $0.8639 * * *$ & $0.8639 * * *$ & - & - \\
\hline & & MG & $1.0167 * * *$ & $0.7702 * * *$ & -1.9975 & 0.3734 & -0.9472 & - & - \\
\hline \multirow{6}{*}{$\begin{array}{c}\text { Kisa } \\
\text { Dönem }\end{array}$} & \multirow{2}{*}{$\begin{array}{l}\text { Sabit } \\
\text { Terim }\end{array}$} & $P M G$ & $0.0246 * * *$ & $0.0574 * * *$ & $0.0497 * * *$ & $0.0448 * * *$ & $0.0280^{* * *}$ & - & - \\
\hline & & MG & $-0.1633 * *$ & $0.3674 *$ & $0.2814 * *$ & $0.2885 * * *$ & $0.2751 * *$ & - & - \\
\hline & \multirow{2}{*}{$\Delta \mathrm{LTÜFE}$} & $P M G$ & $0.7051 * * *$ & -0.0818 & 0.0460 & 0.0401 & -0.0427 & - & - \\
\hline & & MG & $0.4886^{* *}$ & 0.0619 & 0.2131 & 0.1895 & 0.1854 & - & - \\
\hline & \multirow{2}{*}{ ECT } & $P M G$ & $-0.179 * * *$ & $-0.502 * * *$ & $-0.067 * * *$ & $-0.107 * * *$ & $-0.047 * * *$ & - & - \\
\hline & & MG & $-0.2379 *$ & $-0.593 * * *$ & -0.0161 & $-0.0927^{* *}$ & -0.0262 & - & - \\
\hline
\end{tabular}

Not: ***, ** ve * üst simgeleri sirasiyla \%1, \%5 ve \%10 anlamlllık düzeylerinde ilgili katsayının anlamlı olduğunu ifade etmektedir. ECT: Hata düzeltme terimidir.

\section{Sonuç ve Öneriler}

Bu çalışmada Türkiye'de 26 bölge bazında hedonik konut fiyatları ile tüketici fiyatları arasındaki kısa ve uzun dönemli dinamik ilişkilerin panel veri yaklaşımı çerçevesinde test edilmesi amaçlanmıştır. Çalışmanın panel veri seti 26 düzey bölgeden ve 2010:01-2018:02 (üçer aylık) döneminden oluşmaktadır. Hedonik konut fiyat endeksi ile tüketici fiyat endeksi arasındaki uzun dönemli ilişki Kao, Pedroni ve Westerlund panel eşbütünleşme testleriyle analiz edilmişsir. Uzun dönem katsayılarının tahmininde DOLS ve FMOLS yaklaşımlarından yararlanılmıştır. Hedonik konut fiyatları ile tüketici fiyatları arasındaki hem uzun hem de kısa dönemli dinamik ilişsinin tahmini ise PMG ve MG tahmicileri ile gerçekleştirilmiştir.

Uygulanan eşbütünleşme testleri hedonik konut fiyat endeksi ile tüketici fiyat endeksi arasındaki uzun dönem ilişkinin varlığını kanıtlamıştır. DOLS ve FMOLS, tahmincilerinden elde edilen uzun dönem katsayıların birbirlerine oldukça yakın değerlere sahip oldukları ve ilgili katsayıların pozitif ve istatistiksel olarak anlamlı oldukları tespit edilmiştir. $\mathrm{Bu}$ doğrultuda tüketici fiyat endeksinde yaşanacak olan \%10’luk bir artışın hedonik konut fiyat endeksini yaklaşık olarak \%11 düzeyinde artıracağı belirlenmiştir.

Hem uzun hem de kısa dönem dinamiklere ulaşmaya imkan tanıyan PMG ve MG yaklaşımları arasında seçim Hausman testine göre yapılarak uzun dönem parametresinin homojen olduğu tespit edilmiştir. Bu doğrultuda PMG tahmincisinden elde edilen uzun dönem katsayısının yaklaşık olarak 0.85 olduğu, tüketici fiyat endeksinde meydana gelecek \%10'luk bir artışın, hedonik konut fiyat endeksinde yaklaşık olarak \% $8.5^{\prime}$ luk bir artışa sebep olacağı ortaya koyulmuştur. Kısa dönem itibariyle ise tüketici fiyat endeksi katsayısının pozitif ve istatistiksel olarak anlamlı olduğu tespit edilmiştir. Bu sonuç kısa dönemde tüketici fiyat endeksinden hedonik fiyat endeksine doğru nedensellik ilişkisi olduğunu göstermektedir. Ayrıca PMG yaklaşımından edilenilen hata düzeltme katsayısının yaklaşık olarak -0.08 olduğu ve ilgili katsayının beklentiler doğrultusunda değişkenler arasındaki uzun dönem denge ilişkisini doğruladığı saptanmıştır.

Elde edilen bu sonuçlar tüketici fiyatları ile hedonik konut fiyatları arasında kuvvetli bir ilişki olduğunu gösterir niteliktedir. Bununla birlikte, tüketici fiyatlarının hem kısa hem de uzun dönem itibariyle hedonik konut fiyatları üzerinde pozitif bir etkiye sahip olduğu görülmüştür. Önemli bir yatırım aracı olan konuta yatırım yapan bireyler doğal olarak konutun değerini koruma ve artırma kapasitesine önem göstermektedirler. Dolayısıyla konut yatırımcıları için enflasyon riski konutun reel getirisi üzerindeki olumsuz etkisi nedeniyle en önemli endişe kaynağıdır. Çalışmada gerçekleştirilen ampirik analizler neticesinde hedonik konut fiyatlarının uzun dönemde enflasyonla birlikte hareket ettiği ve enflasyona karşı etkili bir koruma sağladığı tespit edilmiştir. Bu doğrultuda yatırımcılar açısından enflasyona karşı önemli bir koruma aracı olan konutun yatırımların reel getirisini artırabileceği ifade edilebilir. Konut fiyatlarının ekonomik dinamiklere olan etkileri ve enflasyona karşı koruma kabiliyeti göz önünde bulundurulduğunda, çalışmadan elde edilen bulguların hem politika yapıcılara hem de yatırımcılara kayda değer bilgiler sağladığı söylenebilir. 


\section{KAYNAKÇA}

Afşar, A., Yılmazel, Ö. ve Yılmazel, S. 2017. “Konut Fiyatlarını Etkileyen Faktörlerin Hedonik Model İle Belirlenmesi: Eskişehir Örneği." Selçuk Üniversitesi Sosyal Bilimler Enstitüsü Dergisi, 37, 195-205.

Akkaya, M. 2018. "Hedonik Konut Fiyat Endeksini Etkileyen Faktörlerin Analizi.” Dokuz Eylül Üniversitesi İktisadi ve İdari Bilimler Fakültesi Dergisi, 33(2), 435-454.

Anari, A. ve Kolari, J. 2002. "House Prices and Inflation." Real Estate Economics, 30(1), 67-84.

Andrews, D. 2010. "Real House Prices in OECD Countries: The Role of Demand Shocks and Structural and Policy Factors." OECD Economics Department Working Paper, No: 831.

Arnold, S. ve Auer, B. R. 2015. "What Do Scientists Know About Inflation Hedging?." North American Journal of Economics and Finance, 34, 187-214.

Badurlar, İ. O. 2008. "Türkiye'de Konut Fiyatları ile Makro Ekonomik Değişkenler Arasındaki İlişkinin Araştırılması.” Anadolu Üniversitesi Sosyal Bilimler Dergisi, 8(1), 223-238.

Baldemir, E., Kesbiç, C. Y. ve İnci, M. 2008. "Estimating Hedonic Demand Parameters in Real Estate Market: The Case of Mugla." Muğla Üniversitesi Sosyal Bilimler Enstitüsü Dergisi, 20.

Baltagi, B., Feng, Q. ve Kao, C. 2012. “A Lagrange Multipier Test for Cross-Sectional Dependence in a Fixed Effects Panel Data Model." Journal of Econometrics, 170(1), 164-177.

Bond, M. ve Seiler, M. 1998. "Real Estate Returns and Inflation: An Added Variable Approach.” Journal of Real Estate Research, 15(3), 327-338.

Breusch, T. S. ve Pagan, A. R. 1980. "The Lagrange Multiplier Test and its Applications to Model Specification in Econometrics." Review of Economic Studies, 47(1), 239-253.

Bulut, H., Yüksel, Ö. ve İslamoğlu, E. 2015. "Samsun İli Konut Fiyatlarını Etkileyen Faktörlerin Hedonik Fiyat Modeli İle İncelenmesi.” Alphanumeric Journal, 3(2), 121-130.

Chang, Y. 2004. "Bootstrap Unit Root Tests in Panels with Cross-Sectional Dependency." Journal of Econometrics, 120(2), 263-293.

Chaudhry, M. K., Myer, F. C. N. ve Webb, J. R. 1999. "Stationarity and Cointegration in Systems with Real Estate and Financial Assets." The Journal of Real Estate Finance and Economics, 18(3), 339-349.

Chu, Y. Q. ve Sing, T. F. 2004. "Inflation Hedging Characteristics of the Chinese Real Estate Market." Journal of Real Estate Portfolio Management, 10(2), 145-154.

Cingöz, A. R. A. A. 2010. "İstanbul'da Kapalı Site Konut Fiyatlarının Analizi.” Sosyal Bilimler Dergisi, 2, $129-139$.

Colwell, P. F. ve Dilmore, G. 1999. "Who Was First? An Examination of an Early Hedonic Study." Land Economics, 75(4), 620-626.

Court, A. T. 1939. "Hedonic Price Indexes with Automotive Examples." The Dynamics of Automobile Demand, 99-117.

Çiçek, U. ve Hatırlı, S. A. 2015. "Isparta İlinde Konut Fiyatlarını Etkileyen Faktörlerin Hedonik Fiyat Modeli İle Analizi." Mehmet Akif Ersoy Üniversitesi SBE Dergisi, 7(13), 98-114.

Erdem, H. F. ve Yamak, N. 2018. "The Long-Run Relationship between Hedonic House Prices and Consumer Prices: ARDL Bounds Testing Approach.” (M. Kenan Terzioğlu Ed.), Econometrics: Methods \& Applications, içinde (19-30), Ankara: Gazi Kitabevi.

Fama, E. F. ve Schwert, G. W. 1977. “Asset Returns and Inflation.” Journal of Financial Economics, 5(2), $115-146$.

Feldstein, M. S. 1980. "Inflation, Tax Rules, and Stock Market.” Journal of Monetary Economics, 6(3), 309-331.

Feldstein, M. S. 1992. "Comment on James M. Poterba's Paper, Tax Reform and The Housing Market in the Late 1980s: Who Knew What, and When Did They Know It." Real Estate and Credit Crunch, Federal Reserve Bank of Boston Conference Series No: 36, 252-257.

Goetzmann, W. N. ve Volaitis, E. 2006. "Simulating Real Estate in the Investment Portfolio: Model Uncertainity and Inflation Hedging." Yale International Centre for Finance Working Paper, No:06-04, 1-39.

Griliches, Z. 1961. "Hedonic Price Indexes for Automobiles: An Econometric Analysis of Quality Change." National Bureau of Economic Research and Univesity of Chicago, 0-87014-072-8, 173-196.

Griliches, Z. 1971. "Introduction: Hedonic Price Indexes Revisited.” Zvi Griliches (Ed.), Price Indexes and Quality Change, içinde (3-15), Cambridge MA: Harvard University Press.

Haas, G. C. 1922. "A Statistical Analysis of Farm Sales in Blue Earth County, Minesota, As a Basis for Farm Land Apprasial." Master Thesis, Univercity of Minesota.

Hausman, J. A. 1978. "Specification Test in Econometrics.” Econometrica, 46(6), 1251-1271.

Hendershott, P. 1980. "Real User Costs an the Demand for Single-Family Housing." Brooking Papers on Economic Activity, 2, 401-452.

Hülagü, T., Kızılkaya, E., Özbekler, A. G. ve Tunar, P. 2016. “Türkiye Konut Fiyat Endeksi’nin Kalite Değişimi Etkisinden Arındırılması: Hedonik Konut Fiyat Endeksi.” Ekonomi Notlarl, TCMB, 2016-2, 1-15.

Inglesi-Lotz, R. ve Gupta R. 2013. "The Long-Run Relationship between House Prices and Inflation in South Africa: An ARDL Approach.” International Journal of Strategic Property Management, 17, 188-198.

İslamoğlu, B. ve Nazlığlu, Ş. 2019. "Enflasyon ve Konut Fiyatları: İstanbul, Ankara ve İzmir İçin Panel Veri Analizi." Siyaset, Ekonomi ve Yönetim Araştırmaları Dergisi, 7(1), 93-99. 
Kangalli Uyar, S. G. ve Yayla, N. 2016. "Konut Fiyatlarinin Hedonik Fiyatlama Yaklaşimina Göre Mekânsal Ekonometrik Modeller İle Tahmini: İstanbul Konut Piyasasi Örneği.” Social Sciences (Nwsasos), 3c0153, 11(4), 326-342.

Kao, C. 1999. "Spurious Regression and Residual-Based Tests for Cointegration in Panel Data." Journal of Econometrics, 90, 1-44.

Kao, C. ve Chiang, M. 2001. "On The Estimation and Inference of A Cointegrated Regression in Panel Data.” Advances in Econometrics, 179-222.

Karaağaç, G. A. ve Altınırmak, S. 2018. “Türkiye Konut Fiyat Endeksi ve Düzey Bazlı Konut Fiyat Endeksleri İle Seçili Değișkenler Arasındaki Nedensellik İlișkisi.” Karadeniz Uluslararası Bilimsel Dergi, 39, 222-240.

Karg1, B. 2013. "Konut Piyasasi ve Ekonomik Büyüme İlişkisi: Türkiye Üzerine Zaman Serileri Analizi (2000-2012)." International Journal of Human Sciences, 10(1), 897-924.

Kaya, A. 2012. “Türkiye'de Konut Fiyatlarını Etkileyen Faktörlerin Hedonik Fiyat Modeli ile Belirlenmesi.” TCMB Uzmanlık Tezi, Ankara.

Kayral, İ. E. 2017. “İstanbul, Ankara ve İzmir Konut Fiyat Değişimlerini Etkileyen Faktörlerin Araştırılması.” Çukurova Üniversitesi IIIBF Dergisi, 21(1), 65-84.

Kearl, J. H. 1979. "Inflation, Mortgages, and Housing." Journal of Political Economy, 87, 1-29.

Kolcu, F. ve Yamak, N. 2018. "Gelir ve Faiz Oranlarının Konut Fiyatları Üzerindeki Kısa ve Uzun Dönem Etkileri." Uluslararası İktisadi ve İdari İncelemeler Dergisi, 141-152.

Kördiş, G., Işık, S. ve Mert, M. 2014. “Antalya'da Konut Fiyatlarını Etkileyen Faktörlerin Hedonik Fiyat Modeli İle Tahmin Edilmesi.” Akdeniz Üniversitesi İktisadi ve İdari Bilimler Fakültesi Dergisi, 28, 103-132.

Lancaster, K. J. 1966. “A New Approach to Consumer Theory.” Journal of Political Economy, 74(2), 132-156.

Lee, H. K. N. 2013. “A Cointegration Analysis of Inflation and Real Estate Returns.” Journal of Real Estate Portfolio Management, 19(3), 207-223.

Ma, L. ve Liu, C. 2008. "Estimating Impact of Consumer Prices on House Prices." In Proceeding of the 37th Australian Conference of Economists, The Economic Society of Australia: Queensland, Avusturalya.

Mutluer, D. 2008. “Gayrimenkul Fiyatlarının Derlenmesi Ülke Örnekleri ve Türkiye İçin Bir Uygulama.” TISK Akademi, 2008/11, 240-278.

Nielsen, S. B. ve Sorensen, P. B. 1994. "Inflation, Capital Taxation, and Housing: The Long Run in a Small Open Economy." Canadian Journal of Economics, 27(1), 198-217.

Paksoy, S., Yöntem, T. ve Büyükçelebi, B. 2014. "Konut Fiyat Endeksi ve Enflasyon Arasındaki İlişki (TRC1, TRC2 ve TRC3 Düzey Bölgeleri Üzerine Ampirik Bir Çalışma).” ASSAM Uluslararası Hakemli Dergi, 2, 54-69.

Pedroni, P. 1996. "Fully Modified OLS for Heterogeneous Cointegrated Panel and The Case of Purchasing Power Parity." Indiana University $W P$

Pedroni, P. 1999. "Critical Values for Cointegration Tests in Heterogeneous Panels with Multiple Regressors.” Oxford Bulletion of Economics and Statistics, 61, 653-670.

Pedroni, P. 2000. "Fully Modified OLS for Heterogeneous Cointegrated Panels." (B. H. Baltagi ve Kao C. D. Eds.), Advances in Econometrics, Volume 15: Nonstationary Panels, Panel Cointegration and Dynamic Panels, içinde (93-130), New York: Elsevier Science.

Pedroni, P. 2004. "Panel Cointegration: Asymptotic and Finite Sample Properties of Pooled Time Series Tests with Application to The PPP Hypothesis." Econometric Theory, 20(3), 597-625.

Persyn, D. ve Westerlund, J. 2008. "Error-Correction-Based Cointegration Tests for Panel Data.” The Stata Journal, 8(2), 232-241.

Pesaran, M. H. ve Smith, R. P. 1995. "Estimating Long-Run Relationship from Dynamic Heterogeneous Panels.” Journal of Econometrics, 68, 79-113.

Pesaran, M. H., Shin, Y. ve Smith, R. P. 1999. "Pooled Mean Group Estimation of Dynamic Heterogeneous Panels." Journal of the American Statistical Association, 94(446), 621-634.

Pesaran, M. H. 2004. "General Diagnostic Tests for Cross Section Dependence in Panels", University of Cambridge, Faculty of Economics, Cambridge WP 0435 in Economics.

Pesaran, M. H. 2007. “A Simple Panel Unit Root Test in the Presence of Cross Section Dependence.” Journal of Applied Econometrics, 22(2), 265-312.

Poterba, J. M. .1992. “Tax Reform and The Housing Market in the Late 1980s: Who Knew What, and When Did They Know It." Real Estate and Credit Crunch, Federal Reserve Bank of Boston Conference Series No: 36, $230-251$.

Reilly, F. K., Marquardt, R. ve Price, D. vd. 1977. "Real Estate as an Inflation Hedge." Review of Business and Economic Research, 12(3), 1-19.

Rosen, S. 1974. "Hedonic Prices and Implicit Markets: Product Differentiation in Pure Competition." Journal of Political Economy, 82(1), 34-55.

Rubens, J., Bond, M. ve Webb, J. 1989. “The Inflation-Hedging Effectiveness of Real Estate.” Journal of Real Estate Research, 4(2), 45-55.

Savuran, O. İ. 2008. Gayrimenkul Fiyat Endeksleri ve İstanbul Etiler Bölgesinde Konutlar İçin Hedonik Fiyat Endeksi Uygulaması, Yayınlanmamış Yüksek Lisans Tezi, İstanbul Teknik Üniversitesi - Fen Bilimleri Enstitüsü.

Selim, S. 2008. "Determinants of House Prices in Turkey: A Hedonic Regression Model.” Doğuş Üniversitesi Dergisi, 9(1), 65-76.

Selim, S. ve Demirbilek, A. 2009. “Türkiye’deki Konutların Kira Değerinin Analizi: Hedonik Model ve Yapay Sinir Ağları Yaklaşımı.” Aksaray Üniversitesi İktisadi ve İdari Bilimler Fakültesi Dergisi, 73-90. 
Sing, T. F. ve Low, S. H. 2000. "The Inflation-Hedging Characteristics of Real Estate and Financial Assets in Singapore." Journal of Real Estate Portfolio Management, 6(4), 373-385.

Spellman, L. J. 1981. "Inflation and Housing Prices.” Real Estate Economics, 9(3), 205-222.

Üçdoğruk, Ş. 2001. "İzmir İlinde Emlak Fiyatlarına Etki Eden Faktörler-Hedonik Yaklaşım.” Dokuz Eylül İktisadi ve İdari Bilimler Fakültesi Dergisi, 16(2), 149-162.

Waugh, V. F. 1928. "Quality Factors Influencing Vegetable Prices.” Journal of Farm Economics, 10(2), 185-196.

Westerlund, J. 2007. "Testing for Error Correction in Panel Data." Oxford Bulletin of Economics and Statistics, 69, 709748.

Yankaya, U. ve Çelik, H. M. 2005. “İzmir Metrosunun Konut Fiyatları Üzerindeki Etkilerinin Hedonik Fiyat Yöntemi İle Modellenmesi." Dokuz Eylül İktisadi ve İdari Bilimler Fakültesi Dergisi, 20(2), 61-79.

Yayar, R. ve Gül, D. 2014. "Mersin Kent Merkezinde Konut Fiyatları Piyasa Fiyatlarının Hedonik Tahmini." Anadolu Üniversitesi Sosyal Bilimler Dergisi, 14(3), 87-99.

Yayar, R. ve Karaca, S. S. 2014. "Konut Fiyatlarına Etki Eden Faktörlerin Hedonik Modelle Belirlenmesi: TR83 Bölgesi Örneği.” Ege Akademik Bakış, 14(4), 509-518.

Zhou, X. ve Clements, S. 2010. "The Inflation Hedging Ability of Real Estate in China." Journal of Real Estate Portfolio Management, 16(3), 267-277. 